Original Article

\title{
Lernaeid parasites prevalence in commercial freshwater fish species at various fish farms in Pakistan
}

\author{
Prevalência de parasitas de Lernaea em espécies comerciais de peixes de água doce em \\ várias pisciculturas no Paquistão
}

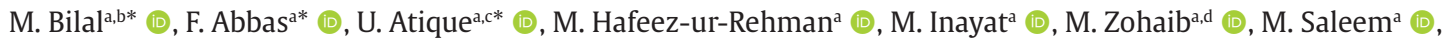

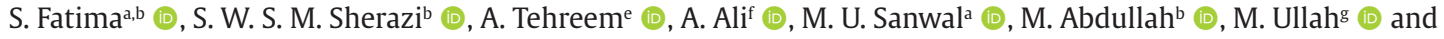 \\ N. Mubeen ${ }^{\mathrm{a}} \mathbb{( 1 )}$ \\ aUniversity of Veterinary and Animal Sciences - UVAS, Department of Fisheries and Aquaculture, Lahore, Pakistan \\ bUniversity of Veterinary and Animal Sciences - UVAS, Institute of Biochemistry and Biotechnology, Lahore, Pakistan \\ ${ }^{c}$ Chungnam National University, Department of Bioscience and Biotechnology, Daejeon, South Korea \\ dUniversity of Lahore, Sargodha Campus, Department of Zoology, Sargodha, Pakistan \\ eUniversity of Agriculture, Department of Zoology, Wildlife and Fisheries, Faisalabad, Pakistan \\ ${ }^{\mathrm{f} C h i n e s e}$ Academy of Sciences, Chengdu Institute of Biology, China \\ Islamia College, Zoology Department, Peshawar, Pakistan
}

\begin{abstract}
Reports abound on Lernaea parasitizing the brood stock, fingerlings, and marketable-sized culturable freshwater fish species in various parts of the world. We investigated seven small-scale aquaculture farms and how the prevailing Lernaea is impacting them. Randomly seven fish farms were selected to determine the prevalence percentage of lernaeid ectoparasites. Relevant information of the fishponds to estimate the various aspects such as effects of water source and quality, feed, stocking density, treatment used, and weight and length of fish, concerned with Lernaea infestation and prevalence was gathered. The results indicated that Catla catla (F. Hamilton, 1822) showed highest prevalence $(41.7 \%$ ) among the seven fish species, whereas Oreochromis niloticus showed zero. Other five fish species Ctenopharyngodon idella, Cirrhinus cirrhosis, Cyprinus carpio, Labeo rohita and Hypophthalmichthys molitrix showed 13.2\%, 8.1\%, 7.7\%, 7.4\%, 0.9\% prevalence, respectively. In Royal Fish Farm 84.3\% lernaeid infestation was observed, while no parasite was observed in the Vicent's Chunnian fish farm. The water source, quality, feed, fertilizers, stocking density, water temperature, and potential treatment options displayed varying tendencies among fish farms and prevalence. Depending on the weight and length, the highest prevalence (56.7\%, and 66.7\%) was observed in 3501-4000 $\mathrm{g}$ and $81-90 \mathrm{~cm}$ groups. The infestation rate varied in various fish body parts with the dorsal fin the most vulnerable organ and showed $2.3 \%$ overall prevalence (while $18.4 \%$ contribution within total $12.6 \%$ infestation). Out of 147 infected fish samples, 45 were extensively contaminated by Lernaea spread. In conclusion, our findings confirm that Lernaea could pose a considerable threat to marketable fish, and various treatment options should be educated to the farmers to help mitigate the spread and potential losses. Furthermore, Catla catla is more vulnerable to Lernaea infestation (41.7\%), so are the fish species being cultured at higher stocking densities.
\end{abstract}

Keywords: C. catla, infestation, Lernaea, pond aquaculture, prevalence.

\begin{abstract}
Resumo
Abundam os relatórios sobre Lernaea parasitando o estoque de cria, alevinos e espécies de peixes de água doce cultiváveis de tamanho comercial em várias partes do mundo. Investigamos sete fazendas de aquicultura de pequena escala e de que maneira a Lernaea predominante está impactando-as. Aleatoriamente, sete fazendas de peixes foram selecionadas para determinar a porcentagem de prevalência de ectoparasitas de Lernaea. Foram recolhidas informações relevantes sobre os viveiros de peixes para estimar os vários aspectos, tais como efeitos da fonte e qualidade da água, alimentação, densidade de povoamento, tratamento utilizado e peso e comprimento dos peixes, relacionados com a infestação e prevalência de Lernaea. Os resultados indicaram que Catla catla (F. Hamilton, 1822) apresentou maior prevalência (41,7\%) entre as sete espécies de peixes, enquanto Oreochromis niloticus apresentou zero. Outras cinco espécies de peixes Ctenopharyngodon idella, Cirrhinus cirrhosis, Cyprinus carpio, Labeo rohita e Hypophthalmichthys molitrix apresentaram 13,2\%, 8,1\%, 7,7\%, 7,4\%, 0,9\% de prevalência, respectivamente. Em Royal Fish Farm, 84,3\% de infestação de Lernaea foi observada, enquanto não se observou nenhum parasita na fazenda de peixes Chunnian de Vicent. A fonte de água, qualidade, ração, fertilizantes, densidade de estocagem, temperatura da água e opções de tratamento potenciais exibiram tendências variadas entre as fazendas de peixes e prevalência. Dependendo do peso e comprimento, a maior prevalência (56,7\% e 66,7\%) foi observada nos grupos
\end{abstract}

*e-mail: muhammadbilallive786@gmail.com; farzana.abbas@uvas.edu.pk; physioatique@gmail.com

Received: July 2, 2021 - Accepted: August 13, 2021

This is an Open Access article distributed under the terms of the Creative Commons Attribution License, which permits unrestricted use, distribution, and reproduction in any medium, provided the original work is properly cited. 
de 3501-4000 g e 81-90 cm. A taxa de infestação variou em várias partes do corpo dos peixes, sendo a nadadeira dorsal o órgão mais vulnerável e apresentou 2,3\% de prevalência geral (enquanto 18,4\% de contribuição dentro do total de 12,6\% de infestação). Das 147 amostras de peixes infectados, 45 estavam amplamente contaminadas pela propagação de Lernaea. Em conclusão, nossos resultados confirmam que Lernaea pode representar uma ameaça considerável para peixes comercializáveis, e várias opções de tratamento devem ser educadas para os agricultores para ajudar a mitigar a propagação e as perdas potenciais. Além disso, Catla catla é mais vulnerável à infestação por Lernaea (41,7\%), assim como as espécies de peixes sendo cultivadas em densidades de estocagem mais altas.

Palavras-chave: $C$. catla, infestação, Lernaea, aquicultura em lago, prevalência.

\section{Introduction}

Aquaculture has emerged as the fastest growing food production sector as well as it is offering reliable alternatives to high quality production of protein (Abbas et al., 2023; Haider et al., 2018; Iqbal et al., 2020a; Jewel et al., 2020). However, it is constantly facing several emerging hazards that are threatening to the sustainable aquaculture production (Batool et al., 2018; Iqbal et al., 2020b; Mehboob et al., 2017; Ray et al., 2021). The pervasiveness of ectoparasites is a significant hazard to the rapidly proliferating aquaculture industry and with its subsequent step at the intensive farming at higher stocking densities. Intensive and semi-intensive culture methods increase the infestation risks by ectoparasites that directly damage the fish body and jeopardize it to the attack of secondary pathogens to invade and cause heavy economic losses (Piasecki et al., 2004), leading to decreased consumer preference and subsequently increased market losses (Iqbal et al., 2020c). One of the most common and dangerous families of ectoparasites of cultured fish species is Lernaeidae (anchor worms), usually associated with parasitism of freshwater fishes.

Among Lernaeidae family of copepods, Lernaea cyprineace (Linnaeus, 1758) is the most frequently occurring and proportionately more dangerous than other sister species. Lernaeid copepods affect fish gills, fins, and body tissues and induce necrosis and disruption. When a female is attached to any body part of fish or specially gills, it leads to severe inflammation, muscular necrosis, and haemorrhage, which paves the way for secondary infections by bacterial and fungal pathogens (Berry Junior et al., 1991; Khalifa and Post, 1976; Lester and Hayward, 2006). Lernaea parasites are discovered everywhere in freshwater and infect several freshwater fish species. They have a high degree of intraspecific morphological variability and interspecific similarities; hence their classification has remained challenging for freshwater fish pathologists.

Some decades ago, studies were conducted to investigate the anchors of Lernaea and are an excellent tool to classify various Lernaea species. However, it is not suitable to entirely rely on the anchors during the classification of these ectoparasites (Hua et al., 2019). Pathogenic Lernaeidae family members cause disease in freshwater fishes worldwide and imply dangerous health effects to infected hosts (Lester and Hayward, 2006). An investigation declared that this parasite has originated from Asia and spread through several regions of the world by the locomotion of farming species by clinging with anchor's help (Innal and Avenant-Oldewage, 2012). This parasite has now been reported worldwide, from Eastern Australia, Asia, Southern Africa, and Europe (Hoffman, 2019; Lester and
Hayward, 2006). It has been observed that fish fingerling mortality is frequently happening due to these parasites' infestation on a global scale. Therefore, it is imperative to study its prevalence, considering the heavy losses incurred (Hemaprasanth et al., 2008).

Previous research has reported that Lernaea cyprinacea (L. cyprinacea) infection has emerged as a significant threat to South Asia's carps culture. It has been recurrently reported from Cirrhinus mrigala (F. Hamilton, 1822), Hypophthalmichthys molitrix (Valenciennes, 1844), Catla catla (F. Hamilton, 1822), Labeo rohita (F. Hamilton, 1822), Ctenopharyngodon idella (Valenciennes, 1844), and Labeo fimbriatus (Bloch, 1795) with variable intensity (Iqbal et al., 2001a; Nandeesha et al., 1984; Nandeesha et al., 1985; Tamuli and Shanbhogue, 1996). However, it has not been reported on Cyprinus carpio (Linnaeus, 1758) and Labeo calbasu (F. Hamilton, 1822) from the same geographical region. Later, Hemaprasanth et al. (2011) first reported the $L$. cyprinacea infestation in the C. carpio reared in the polyculture system.

District Kasur of Punjab, Pakistan, is a vital fish farming zone as the Ravi River bounds it in the north-west and river Sutlej in the south-east along the bordering region of India (Atique et al., 2020). Simultaneously, Beas River's old course bifurcates the district into two equal parts locally known as Hither and Uthar or Mithan Majh. It is considered the primary fish market in Punjab province, competing for Lahore, Rawalpindi, Gujranwala, Faisalabad, Multan, and Sahiwal. Apart from valuable catch fisheries, several fish farms have been developed to boost this economically vital region's aquaculture potential. Head Baloki, Changa Manga, Chunian, and the University of Veterinary and Animal Sciences (UVAS) fish farms are some of the most crucial aquaculture hotspots promoting. Recently, local fish farmers have reported Lernaea infestation's prevalence in their small-scale to large-scale fish farms.

Therefore, considering the importance of the Kasur region, we planned this study to investigate the Lernaea infestation and prevalence from various fish farms of private and public proprietorship. We aimed at investigating the presence, load, and prevalence of Lernaea in seven commercially important aquaculture fish species in Pakistan.

\section{Material and Methods}

\subsection{Ethics statement}

The authors confirm that the ethical policies of the journal, as noted on the journal's author guidelines page, have been adhered to and the appropriate ethical review 
committee approval has been received from Ethical Review Committee, Office of Research, Innovation \& Commercialization, University of Veterinary and Animal Sciences, Lahore, Pakistan. The given methods of Restraint, Handling and Protocols for Lab Animals were followed.

\subsection{Study area and fish sampling for Lernaea prevalence}

Seven randomly selected public and privately-owned fish farms in district Kasur, Punjab, Pakistan were targeted for the study (see Figure 1). A questionnaire was prepared to collect the intended information about fish farming's various aspects by directly investigating the fish farms' owners/managers. Fish samples from the surveyed fish farms using seine net and cast/throw nets on a bi-monthly basis from August 2019 to January 2020 were collected. Total 1164 fish samples were examined, including 323 of Rohu (L. rohita), 422 Grass carp (C. idella), 37 Mori (C. cirrhosis), 144 Thaila (C. catla), 107 Silver carp (H. molitrix), 105 Tilapia (Oreochromis niloticus, Linnaeus, 1758) and 26 of common carp (C. carpio) for potential Lernaea infestation and prevalence. The fish body weight and length were also measured. Lernaea were observed on different body organs and the fish body to check parasite's organ specificity, including lateral, dorsal, ventral, caudal, pectoral fin, anal region, gills, eyes, mouth, and snout of the fish. Using forceps and $\mathrm{KMnO}_{4}$ solution for easy detachment Lernaea parasites were removed from the commercially harvested fish and preserved in the centrifuge tubes using $10 \%$ formalin and $95 \%$ ethanol solutions for further identification at the laboratory.

\subsection{Morphology of Lernaea}

Lernaea samples isolated from fish were brought to the fish diagnostic and health management lab of Fisheries and Aquaculture Department, UVAS, Ravi Campus, Pattoki for species identification. The identification key of Kabata (1985), Margolis and Kabata (1988) and Monod (1932) were followed.

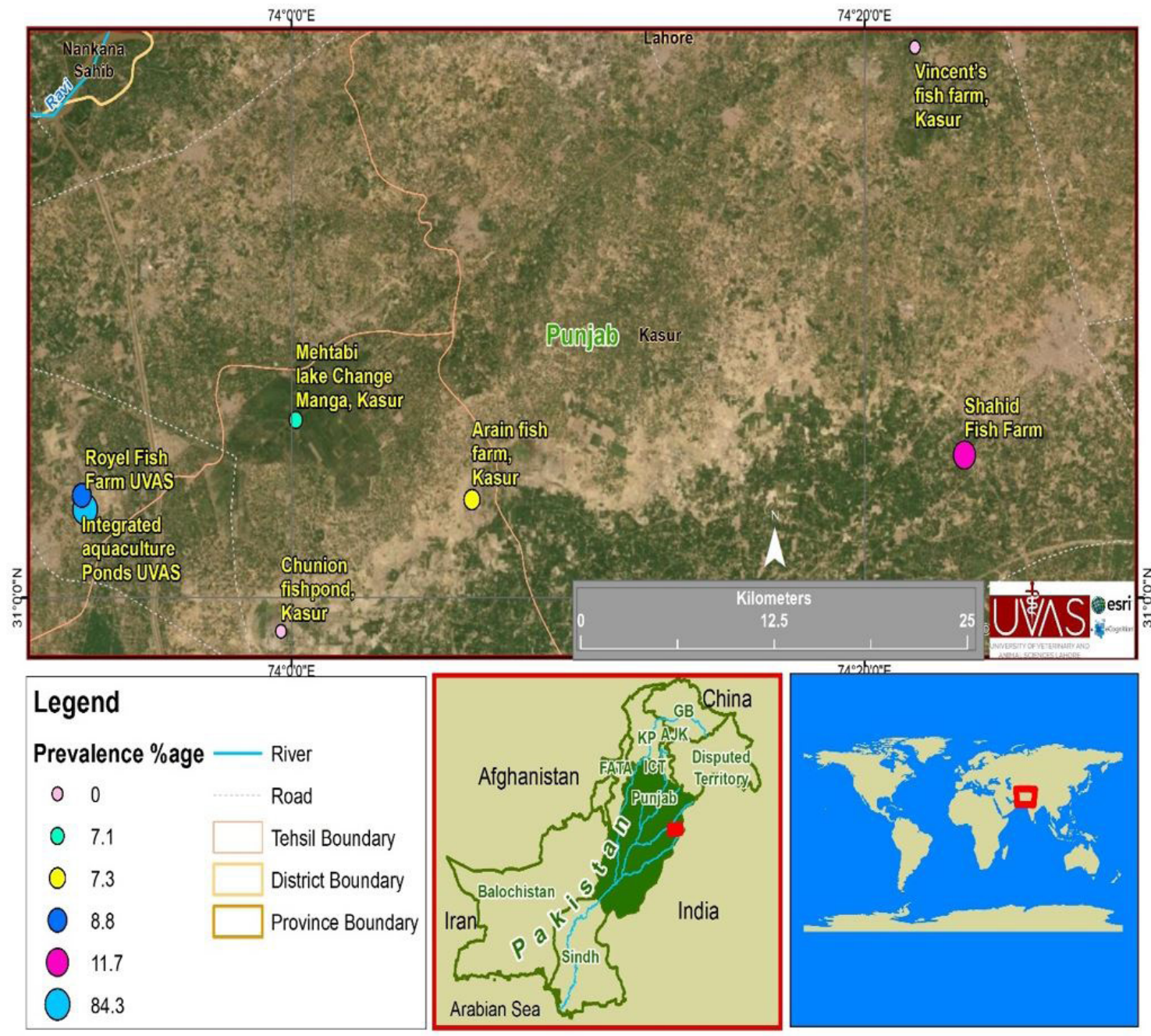

Figure 1. Map showing localities studied during this research trial. 


\subsection{Statistical analysis}

For the statistical analysis, the data was checked for its normality before treating for statistical evaluations. The obtained dataset was analyzed with the help of statistical package for social sciences (SPSS, v. 21). To compare the various farms and fish species, we used the Chi-square test. The obtained results were presented in tables.

\section{Results}

The data from seven fish farms showed that most of the time all the fish farmers used underground water pumped out with tube-well water for aquaculture. However, some of the farms also relied upon the combination of tube-well, rain, and canal water as the water resources (Chunnian and Shahid fish farms). These fish farms displayed varying prevalence tendencies of Lernaea (as shown in Table 1). Farms using water from sources other than the tube-well indicated lower Lernaea prevalence than the farms using tube-well water only. Similarly, farms that used manure and other fertilizers showed zero prevalence than the farms utilizing urea or diammonium phosphate (DAP) for pond fertilization. Treatments used to disinfect ponds before culturing aquaculture species and during pond management also influence disease rate and lernaea prevalence (as shown in Table 1 ).

Most fish farmers cultured Indian major carps and Chinese carps except for Chunian Fish Farm that stocked tilapia. The farm area differed significantly; however, the stocking density did not indicate dense fish stocking signs that could cause higher chances of parasitic outbreaks. Stocking density with respect to the pond area also showed an essential connection to the Lernaea infestation. Farms with higher stocking density showed a heavy Lernaea infestation, whereas applications of lime reduced the infestation. It was also noticed that pond liming was the best treatment option for Lernaea control. The selected water

Table 1. Farm and feeding details along with the potential infestation and treatment methods of Lernaea at the seven fish farms surveyed during the study.

\begin{tabular}{|c|c|c|c|c|c|c|c|c|c|}
\hline Fish Farm & Size & $\begin{array}{l}\text { Water } \\
\text { source }\end{array}$ & Feed & $\begin{array}{c}\% \text { Feed } \\
\text { given }\end{array}$ & Fertilizer & $\begin{array}{c}\text { Stocking } \\
\text { density/ } \\
\text { acre }\end{array}$ & $\begin{array}{c}\text { Fish } \\
\text { Species }\end{array}$ & $\begin{array}{c}\text { Lernaea } \\
\text { infestation }\end{array}$ & Treatment used \\
\hline $\begin{array}{l}\text { Royal Fish Farm, } \\
\text { UVAS, Pattoki }\end{array}$ & 2 acres & Tube well & $\begin{array}{l}\text { AMG Fish } \\
\text { Feed } 22 \% \\
\text { CP }\end{array}$ & $2 \%$ & $\begin{array}{l}\text { Manure, } \\
\text { Urea }\end{array}$ & 1000 & $\begin{array}{l}\text { Rahu, Mori, } \\
\text { Thella, } \\
\text { Silver, } \\
\text { Grass }\end{array}$ & 84.3 & Liming, $\mathrm{KMnO}_{4}$ \\
\hline $\begin{array}{l}\text { Integrated } \\
\text { Aquaculture } \\
\text { Fish Farms, } \\
\text { UVAS, Pattoki }\end{array}$ & 1 acre & Tube well & $\begin{array}{l}\text { Supreme } \\
\text { Feed }(25 \% \\
\text { CP) }\end{array}$ & $2 \%$ & $\begin{array}{l}\text { Duck } \\
\text { droppings, } \\
\text { Urea }\end{array}$ & 800 & $\begin{array}{l}\text { Rahu, } \\
\text { Mori, } \\
\text { Grass carp }\end{array}$ & 8.8 & Organophosphates \\
\hline $\begin{array}{l}\text { Mehtabi Lake } \\
\text { Change Manga }\end{array}$ & 8 acres & Tube well & $\begin{array}{l}\text { Rice } \\
\text { polish, } \\
\text { Wheat } \\
\text { bran, } \\
\text { Soya been }\end{array}$ & $2 \%$ & $\begin{array}{l}\text { DAP, } \\
\text { Urea }\end{array}$ & 2000 & $\begin{array}{l}\text { Rahu, Mori, } \\
\text { Thella, } \\
\text { Grass carp, } \\
\text { Silver, } \\
\text { Hybrid } \\
\text { (Rahu + } \\
\text { Thella) }\end{array}$ & 7.1 & $\begin{array}{l}\text { Liming, } \\
\mathrm{KMnO}_{4}\end{array}$ \\
\hline $\begin{array}{l}\text { Vincent's Fish } \\
\text { Farm }\end{array}$ & 3 acres & Tube well & $\begin{array}{l}\text { Forage / } \\
\text { Fodder }\end{array}$ & $2-4 \%$ & $\begin{array}{l}\text { DAP, Urea, } \\
\text { Manure }\end{array}$ & 800 & $\begin{array}{l}\text { Grass carp, } \\
\text { Rahu, } \\
\text { Thella }\end{array}$ & 0 & Liming \\
\hline $\begin{array}{l}\text { Arain Fish } \\
\text { Farm, Kasur }\end{array}$ & 4 acres & Tube well & Rice police & $1.5-2.5 \%$ & $\begin{array}{l}\text { DAP, } \\
\text { Urea, } \\
\text { Manure }\end{array}$ & 1000 & $\begin{array}{l}\text { Rahu, } \\
\text { Thella, } \\
\text { Mori, } \\
\text { Grass carp, } \\
\text { Common } \\
\text { carp }\end{array}$ & 7.3 & Liming \\
\hline $\begin{array}{l}\text { Chunian Fish } \\
\text { Farm, Kasur }\end{array}$ & 1 acre & $\begin{array}{l}\text { Rain, Canal } \\
\text { water, Tube } \\
\text { well }\end{array}$ & $\begin{array}{l}\text { Forage, } \\
\text { Husk, } \\
\text { Cow dung, } \\
\text { Fertilizer, } \\
\text { Rice polish }\end{array}$ & $2-4 \%$ & Manure & 1200 & Tilapia & 0 & Liming \\
\hline $\begin{array}{l}\text { Shahid Fish } \\
\text { Farm, Kasur }\end{array}$ & 2 acres & $\begin{array}{l}\text { Tube well, } \\
\text { Canal water }\end{array}$ & $\begin{array}{l}\text { Rice } \\
\text { polish, } \\
\text { Maize } \\
\text { gluten, } \\
\text { Soya been }\end{array}$ & $2 \%$ & $\begin{array}{l}\text { DAP, } \\
\text { Urea, } \\
\text { Manure }\end{array}$ & 1000 & $\begin{array}{l}\text { Rahu, } \\
\text { Thella, } \\
\text { Mori, } \\
\text { Grass carp }\end{array}$ & 11.7 & $\begin{array}{l}\text { No treatment } \\
\text { measures taken }\end{array}$ \\
\hline
\end{tabular}


quality parameters were observed within the acceptable ranges for aquaculture practices (as shown in Table 2).

A total of 1164 samples of freshwater fish species were examined from seven fish farms, among which only 147 (12.6\%) samples were observed with the Lernaea infestation. Total 12 species of Lernaea, that included $L$. cyprinacae, L. cruciata, L. polymorpha, L. ctenopharyngodanis, L. devastatrix, L. lophiara, L. multilobosa, L. temnocephala, L. esocina, L. barnimiana, and two unidentified species of Lernaea due to potential sample damages or difficulties in identification were observed in this study (see Figure 2a-1). The most common species observed in this study was the L. cyprinacea. The various body organs of fish for possible anchoring of the parasites were observed, and the details are shown in Figure 3. It shows the hotspots of Lernaea on the whole fish body, head and snout, and around the eye.

The highest Lernaea infestation was observed at the Royal fish farm (84.3\%), Integrated Aquaculture Fish Farm, UVAS, Pattoki (8.8\%), whereas the lowest (no infestation) was observed at the Vicent's and Chunian fish farm (as shown in Table 3). Among the seven fish species sampled during the study, the highest prevalence of Lernaea was observed on C. catla (41.7\%), C. idella (13.2\%), C. mrigala (8.1\%), C. carpio (7.7\%), and L. rohita (7.4\%). In contrast, no Lernaea infestation was observed on 0 . niloticus (as shown in Table 4).

This study explored the most vulnerable weight and length stages of cultured fish species to the Lernaea infestation. The results concluded that Lernaea had a different prevalence in the various age groups (as shown in Table 5). For instance, $C$. mrigala and $C$. carpio showed higher prevalence in lower body weight groups, while $C$. catla, C. idella and H. molitrix showed higher prevalence at older stages or higher weight groups (3000 - 4000g). The highest prevalence (56.7\% and 66.7\%) was observed in the 3501-4000 g and 81-90 cm groups, respectively. For $L$. rohita, $C$. idella, $C$. mrigala, $H$. molitrix and $C$. carpio, the highest prevalence was recorded as $75.0 \%, 29.7 \%, 50.0 \%$, $25.0 \%$ and $50.0 \%$ within $3501-4000 \mathrm{~g}, 501-1000 \mathrm{~g}, \leq 500 \mathrm{~g}$, 3501-4000 g and $\leq 500 \mathrm{~g}$ weight groups, respectively.

Table 2. Records of the selected water quality parameters and vegetation types at the surveyed fish farms.

\begin{tabular}{|c|c|c|c|c|c|c|c|}
\hline Fish farm & Vegetation & WT $\left({ }^{\circ} \mathrm{C}\right)$ & $\mathbf{p H}$ & $\mathrm{DO}(\mathrm{mg} / \mathrm{L})$ & BOD & TSS (mg/L) & $\begin{array}{c}\text { Salinity } \\
(\%)\end{array}$ \\
\hline $\begin{array}{l}\text { Royal Fish Farm, } \\
\text { UVAS, Pattoki }\end{array}$ & $\begin{array}{l}\text { Grasses, } \\
\text { Weeds, } \\
\text { Algae, Fungi }\end{array}$ & $14 \pm 19$ & $8.9 \pm 1.0$ & $7.5 \pm 1.4$ & $5.8 \pm 0.2$ & $10.0 \pm 0.3$ & $10.0 \pm 0.2$ \\
\hline $\begin{array}{l}\text { Integrated } \\
\text { Aquaculture Ponds } \\
\text { UVAS, Pattoki }\end{array}$ & $\begin{array}{l}\text { Algae, } \\
\text { Grasses }\end{array}$ & $15 \pm 15$ & $7.5 \pm 1.5$ & $7.1 \pm 0.4$ & $4.2 \pm 0.1$ & $8.0 \pm 0.7$ & $6.5 \pm 0.4$ \\
\hline $\begin{array}{l}\text { Mehtabi Lake, } \\
\text { Change Manga }\end{array}$ & Algae & $23 \pm 10$ & $7.3 \pm 1.1$ & $6.3 \pm 0.7$ & $3.9 \pm 0.1$ & $7.1 \pm 0.9$ & $7.9 \pm 0.3$ \\
\hline $\begin{array}{l}\text { Vincent's Fish Farm, } \\
\text { Kasur }\end{array}$ & $\begin{array}{l}\text { Algae, } \\
\text { Weeds }\end{array}$ & $15 \pm 14$ & $6.9 \pm 1.3$ & $7.2 \pm 0.7$ & $3.0 \pm .3$ & $4.0 \pm 1.3$ & $4.5 \pm 0.5$ \\
\hline $\begin{array}{l}\text { Arain Fish Farm, } \\
\text { Kasur }\end{array}$ & $\begin{array}{l}\text { Grasses, } \\
\text { Algae }\end{array}$ & $19 \pm 15$ & $7.1 \pm 0.9$ & $6.4 \pm 1.4$ & $3.7 \pm 0.1$ & $5.5 \pm 0.9$ & $5.6 \pm 0.9$ \\
\hline $\begin{array}{l}\text { Chunian Fish Farm, } \\
\text { Kasur }\end{array}$ & Algae & $12 \pm 16$ & $7.0 \pm 1.5$ & $6.5 \pm 05$ & $2.9 \pm 0.4$ & $3.2 \pm 0.6$ & $4.0 \pm 0.1$ \\
\hline $\begin{array}{l}\text { Shahid Fish Farm, } \\
\text { Kasur }\end{array}$ & $\begin{array}{l}\text { Grasses, } \\
\text { Algae, } \\
\text { Weeds }\end{array}$ & $16 \pm 15$ & $8.7 \pm 1.3$ & $6.8 \pm 0.6$ & $3.5 \pm 0.3$ & $6.0 \pm 0.9$ & $8.3 \pm 0.8$ \\
\hline
\end{tabular}

$\mathrm{WT}$ = water temperature; $\mathrm{DO}=$ Dissolved oxygen; $\mathrm{BOD}=$ biological, oxygen demand; TSS = Total suspended solids .

Table 3. Percentage prevalence of Lernaea at surveyed fish farms.

\begin{tabular}{lccc}
\hline \multicolumn{1}{c}{ Fish Farm } & Samples & Samples infected & \% Prevalence \\
\hline Royal Fish Farm, UVAS, Pattoki & 89 & 75 & 84.3 \\
Integrated Aquaculture Ponds UVAS, Pattoki & 57 & 5.8 & 7.1 \\
Mehtabi Lake, Change Manga & 70 & 5 & 0 \\
Vincent's Fish Farm, Kasur & 47 & 0 & 7.3 \\
Arain Fish Farm, Kasur & 702 & 51 & 0 \\
Chunian Fish Farm, Kasur & 105 & 0 & 11 \\
Shahid Fish Farm, Kasur & 94 & $\mathbf{1 1 . 7}$ \\
Total & $\mathbf{1 1 6 4}$ & $\mathbf{1 4 7}$ \\
\hline
\end{tabular}



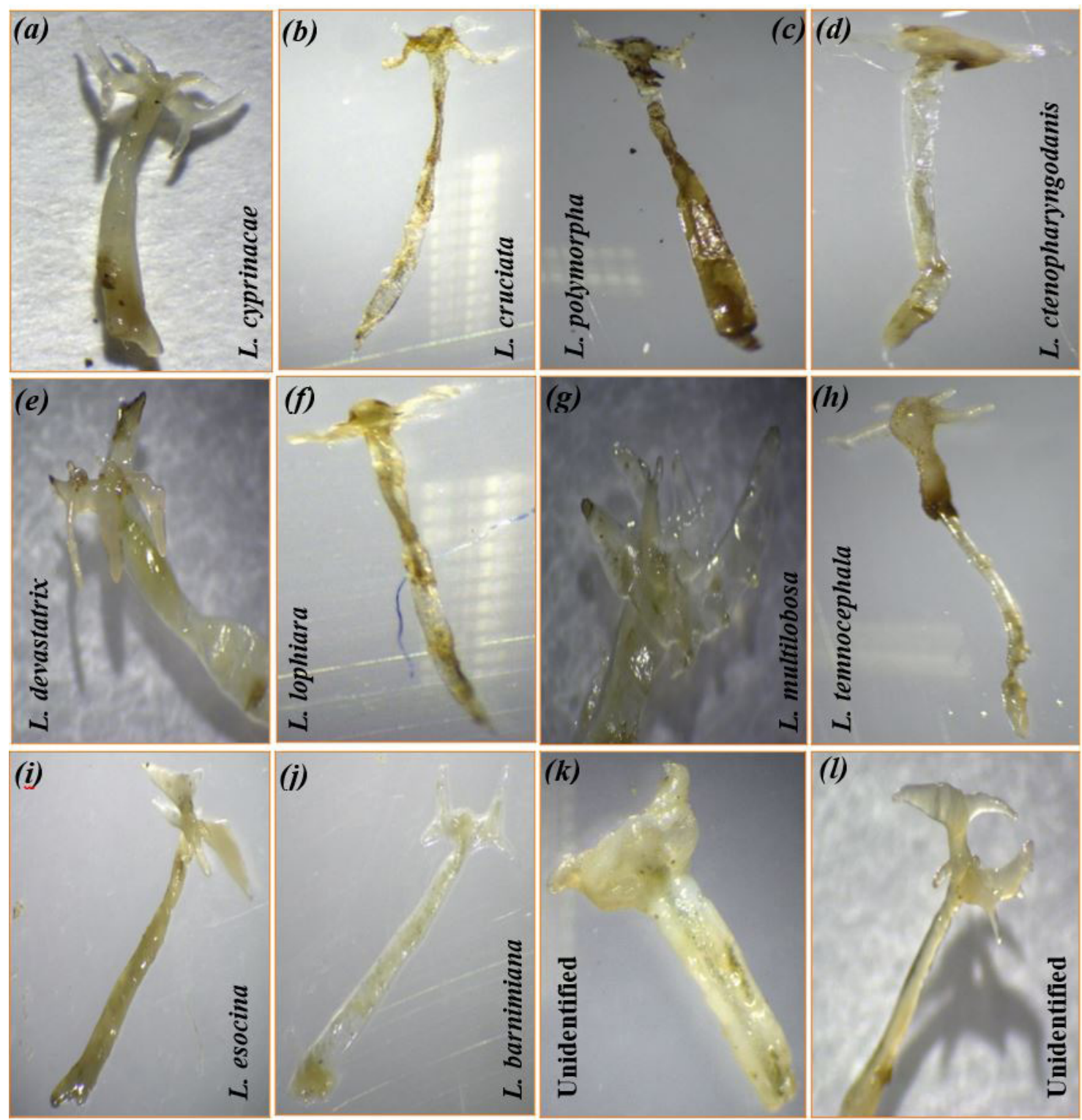

Figure 2. Snapshot of prevalent Lernaea species identified $(\mathrm{a}-\mathrm{j})$ and unidentified $(\mathrm{k}-\mathrm{l})$ during the survey of various fish farms.

Table 4. Lernaea prevalence with respect to fish species cultured at fish farms.

\begin{tabular}{lccc}
\hline \multicolumn{1}{c}{ Fish species } & Examined Samples & Infected Samples & Prevalence (\%) \\
\hline Labeo rohita & 323 & 24 & 7.4 \\
Ctenopharyngodon idella & 422 & 58 & 13.2 \\
Cirrhinus cirrhosis & 37 & 3 & 8.1 \\
Catla catla & 144 & 60 & 41.7 \\
Hypophthalmichthys molitrix & 107 & 1 & 0.9 \\
Cyprinus carpio & 26 & 2 & 7.7 \\
Oreochromis niloticus & 105 & 0 & 0 \\
Total & $\mathbf{1 1 6 4}$ & $\mathbf{1 4 7}$ & $\mathbf{1 2 . 6}$ \\
\hline
\end{tabular}


Table 5. Percentage prevalence of Lernaea with respect to weight and length of observed fish species.

\begin{tabular}{|c|c|c|c|c|c|c|c|}
\hline $\begin{array}{c}\text { Weight } \\
\text { and Length } \\
\text { categories }\end{array}$ & L. rohita & C. idella & C. cirrhosis & C. catla & H. molitrix & C. carpio & $\begin{array}{c}\text { Total } \\
\text { prevalence } \\
(\%)\end{array}$ \\
\hline$\leq 500 \mathrm{~g}$ & $7.1 \%$ & $27.8 \%$ & $50 \%$ & $16.7 \%$ & $0 \%$ & $50 \%$ & $13.3 \%$ \\
\hline $10-20 \mathrm{~cm}$ & $0 \%$ & $7 \%$ & - & $16.7 \%$ & $0 \%$ & - & $2.9 \%$ \\
\hline $501-1000 \mathrm{~g}$ & $4.2 \%$ & $29.7 \%$ & $9.1 \%$ & $5.9 \%$ & $0 \%$ & $0 \%$ & $12.7 \%$ \\
\hline $21-30 \mathrm{~cm}$ & $11.1 \%$ & $41.5 \%$ & $50 \%$ & $9.1 \%$ & $0 \%$ & $50 \%$ & $20 \%$ \\
\hline $1001-1500 \mathrm{~g}$ & $0 \%$ & $5.2 \%$ & $6.7 \%$ & $0 \%$ & $0 \%$ & - & $2.6 \%$ \\
\hline $31-40 \mathrm{~cm}$ & $0.8 \%$ & $28.8 \%$ & $6.7 \%$ & $0 \%$ & $0 \%$ & $0 \%$ & $8.1 \%$ \\
\hline $1501-2000 \mathrm{~g}$ & $2.7 \%$ & $0 \%$ & $0 \%$ & $0 \%$ & $0 \%$ & $0 \%$ & $0.6 \%$ \\
\hline $41-50 \mathrm{~cm}$ & $1.8 \%$ & $2.9 \%$ & $9.1 \%$ & $6.7 \%$ & - & - & $2.9 \%$ \\
\hline $2001-2500 \mathrm{~g}$ & $22.2 \%$ & $0 \%$ & $0 \%$ & $33.3 \%$ & $0 \%$ & $5.3 \%$ & $8.9 \%$ \\
\hline $51-60 \mathrm{~cm}$ & $13.3 \%$ & $1.4 \%$ & $0 \%$ & $29.4 \%$ & $0 \%$ & $0 \%$ & $8.4 \%$ \\
\hline $2501-3000 \mathrm{~g}$ & $60 \%$ & $4.1 \%$ & - & $63.3 \%$ & $0 \%$ & $0 \%$ & $30 \%$ \\
\hline $61-70 \mathrm{~cm}$ & $50 \%$ & $50 \%$ & $0 \%$ & $85 \%$ & $0 \%$ & $5.9 \%$ & $25.2 \%$ \\
\hline $3001-3500 \mathrm{~g}$ & $42.9 \%$ & $12 \%$ & - & $84.6 \%$ & $0 \%$ & - & $39.4 \%$ \\
\hline $71-80 \mathrm{~cm}$ & $57.1 \%$ & $21.2 \%$ & - & $76.5 \%$ & $20 \%$ & $0 \%$ & $39.7 \%$ \\
\hline $3501-4000 \mathrm{~g}$ & $75 \%$ & $38.5 \%$ & - & $88.9 \%$ & $25 \%$ & - & $56.7 \%$ \\
\hline $81-90 \mathrm{~cm}$ & $66.7 \%$ & - & - & - & - & - & $66.7 \%$ \\
\hline Total & $7.4 \%$ & $13.7 \%$ & $8.1 \%$ & $41.7 \%$ & $0.9 \%$ & $7.7 \%$ & \\
\hline
\end{tabular}

The relationship between length and infestations of Lernaea showed that the highest prevalence was $66.7 \%, 50.0 \%$, $50.0 \%, 20.0 \%$, and $50.0 \%$ within $71-80 \mathrm{~cm}, 61-70 \mathrm{~cm}, 21-$ $30 \mathrm{~cm}, 71-80 \mathrm{~cm}$, and $21-30 \mathrm{~cm}$ length groups for $L$. rohita, C. idella, C. cirrhosis, H. molitrix and C. carpio, respectively (as shown in Table 5).

The fish body was distributed into 12 zones and examined for potential hotspots of Lernaea infestation (see Figure 3). It was observed that the dorsal fin was the most vulnerable part of the fish body and showed $2.3 \%$ overall prevalence (while $18.4 \%$ contribution within total $12.6 \%$ infestation). The highest prevalence was recorded for different species within different body part was $0.5 \%$, $1.3 \%, 0.2 \% 0.9 \%$ and $0.1 \%$ in L. rohita, C. idella, C. cirrhosis, C. catla, and H. molitrix, regarding dorsal fin for the first three species and the fifth one but ventrodorsal and lateral body region for $C$. catla. Among the samples, 45 (30.6\%) were infected with all body parts, especially in $C$. catla (32 pieces), with an infestation on the eyes and head region. One $L$. rohita was infested on its snout region, while another sample of $C$. idella was infested on the head region (as shown in Table 6).

The fish sampling was performed bi-monthly (Aug-Sep, Oct-Nov, and Dec-Jan), and the prevalence during these periods are presented in Table 7. The highest infestation was $13.6 \%$ observed during Dec-Jan, while $8.3 \%$ and 3.3\% were recorded during Aug-Sep and Oct-Nov, respectively. The individual percentage of infestation also recorded for different species studied during these periods. The highest prevalence was observed on L. rohita (5\%) during Aug-Sep and for C. idella (14.5\%), C. cirrhosis (9.4\%), C. catla (45.8\%), H. molitrix (1\%), and C. carpio (7.7\%) were recorded during Dec-Jan.

\section{Discussion}

Lernaeidae occupies a unique position owing to their extraordinary pathogenic effect and financial damages in fish farming. Specifically, the L. cyprinacea (Linnaeus, 1758) is the primary causative agent of lernaeaosis in Indian Major carps and Chinese carps and turns the saleable fisheries products nonsalable because it inflicts severe tegumentary lesions (Tavares-Dias and Martins, 2017). Furthermore, such parasitic diseases can demote reproductive ability and negatively influence feed conversion efficiency in fish, causing a decline in fish growth and cultured fish's overall performance. The present study aimed at investigating the Lernaea prevalence in commercial and public fish farms in district Kasur, Pakistan. We collected the relevant data from the farm owners and managers about pond inputs, water quality, overall pond status, Lernaea prevalence, and potential strategies to control it by using a questionnaire. The Lernaea samples collected from the fish species and their identification indicated ten known species viz. L. cyprinacea, Lernaea polymorpha (Yü, 1938), Lernaea cruciata (Lesueur, 1824), Lernaea ctenopharyngodanis (Yin, 1961), Lernaea devastatrix (Boxshall, Montú \& Schwarzbold, 1997), Lernaea lophiara (Harding, 1950), Lernaea multilobosa (Jafri and Mahar, 2003), Lernaea temnocephala (Cunnington, 1914), Lernaea esocina (Burmeister, 1835), and Lernaea barnimiana (Hartmann 1865). However, we also recorded two unknown species owing to difficulties in species identification based on morphological characteristics. The other reasons could also include the damage of samples during Lernaea removal from the fish skin and organs. Iqbal et al. (2012) have reported L. cyprinacea, $L$. polymorpha and Lernaea oryzophila (Monod, 1932) on $L$. rohita and C. idella. L. ctenopharyngodonis and some other 

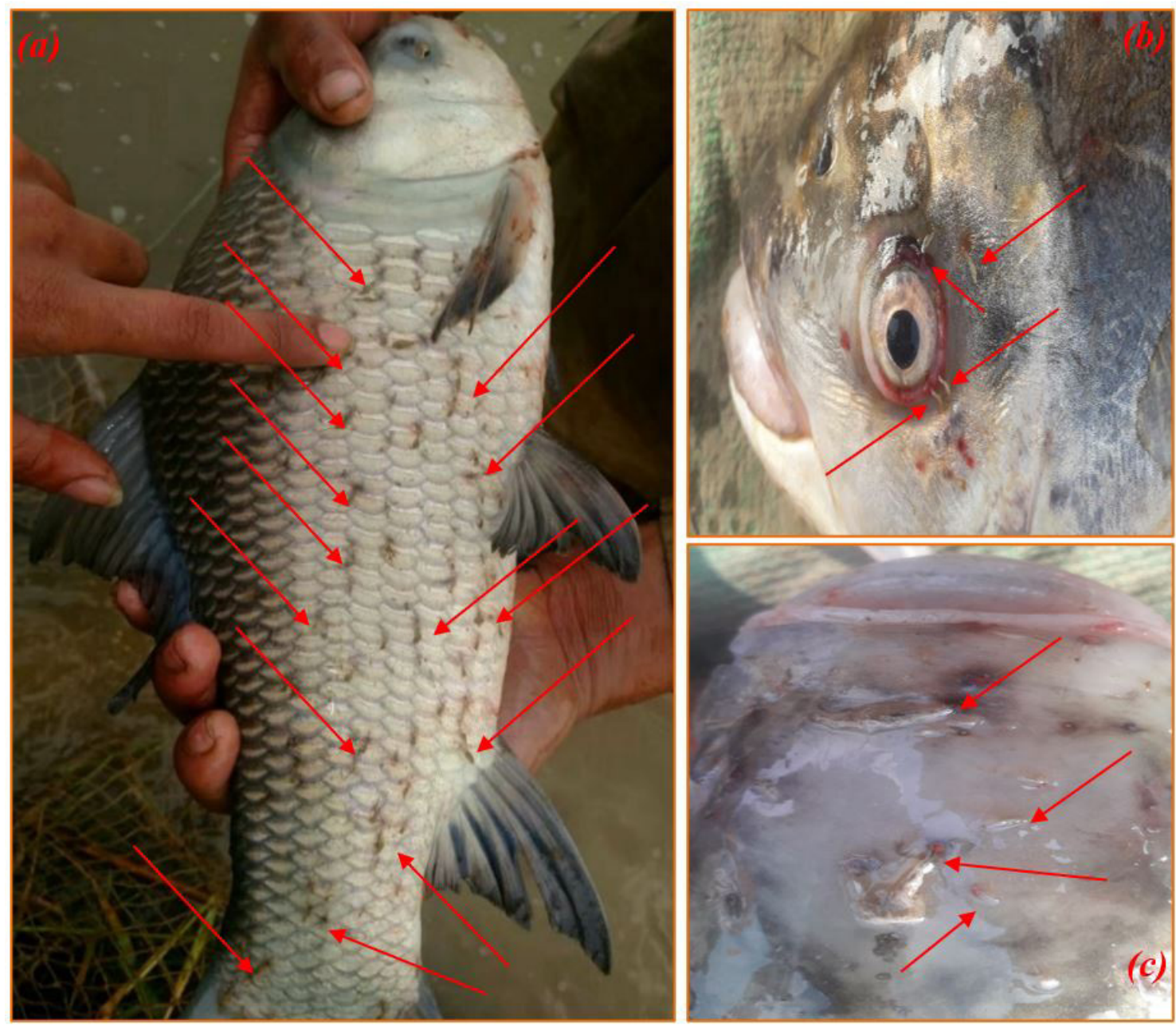

Figure 3. Hotspots of Lernaea on fish body (a), around the eye (b) and snout (c), identified during the survey.

unknown species of Lernaea from the University of the Punjab research fish farms. The L. cyprinacea was the most prevalent and dominant. Outcomes of Hemaprasanth et al. (2008) and Tasawar et al. (2007) also corroborated our findings. The Lernaea species are cosmopolitan parasites of several freshwater fish species reported from all the countries famous for fish culture. However, their classification and identification are controversial due to morphological intraspecific variability and interspecific similarities (Hua et al., 2019).

The fish samples collected from various aquaculture ponds showed that ponds fed with tube well for their freshwater supply were the most affected. Among all specimens examined, the highest prevalence was observed in C. catla (41.7\%). Tasawar et al. (2007) reported 96 out of 120 C. catla fish samples as infested, showing an overall prevalence of $80 \%$. Abbas et al. (2014) presented that not a single lernaeid ectoparasite specimen was observed on C. carpio, and it emerged as the most resistant fish species among Chinese and Indian major carps. However, our results report 7.7\% Lernaea prevalence in C. carpio. Rahnama et al.
(2016) studied 10.7\% prevalence of Lernaea species reported from 107 infected C. carpio samples out of 1000, while a $30.1 \%$ prevalence was calculated by Sayyadzadeh et al. (2016), with these studies in close approximation with our research. Piasecki et al. (2004) reported C. carpio as the best-known host for lernaeid species. Heavy Lernaea infestation in $C$. catla recorded during the current study could be due to considerable fish body weight, slow movement, feeding preferences in the pond where Lernaea growth conditions were in an optimum range. Such energy crises result in lethargy and immune deficiency in fish that make them more vulnerable to Lernaea infestation and secondary infections. These findings suggest that a species could be non-affected in one part, but the same species could be highly infected in other parts of the world, alluding to infestation uncertainty.

The maximum prevalence at the dorsal fin followed by the caudal fin was observed, which corroborates several previous findings and indicates the most favorite places for the anchoring parasites (Iqbal et al., 2012; Innal et al., 2017; Mirzaei, 2015; Stavrescu-Bedivan et al., 2014). 
Table 6. Prevalence (\%) of Lernaea with respect to different body parts in different fish species observed.

\begin{tabular}{|c|c|c|c|c|c|c|c|c|}
\hline Body part & $\begin{array}{l}\text { L. rohita } \\
\text { (\%) }\end{array}$ & $\begin{array}{l}\text { C. idella } \\
\text { (\%) }\end{array}$ & $\begin{array}{l}\text { C. cirrhosis } \\
\text { (\%) }\end{array}$ & $\begin{array}{l}\text { C. catla } \\
(\%)\end{array}$ & $\begin{array}{l}\text { H. molitrix } \\
\text { (\%) }\end{array}$ & $\begin{array}{l}\text { C. carpio } \\
\text { (\%) }\end{array}$ & Total (\%) & $\begin{array}{l}\% \text { Of } 12.6 \% \\
\text { infestation }\end{array}$ \\
\hline Lateral line & $5(0.4)$ & $1(0.1)$ & $1(0.1)$ & $1(0.1)$ & - & - & $8(0.7)$ & 5.4 \\
\hline Dorsal fin & $6(0.5)$ & $15(1.3)$ & $2(0.2)$ & $3(0.3)$ & $1(0.1)$ & - & $27(2.3)$ & 18.4 \\
\hline Ventral body plane & - & $5(0.4)$ & - & $2(0.2)$ & - & - & $7(0.6)$ & 4.8 \\
\hline $\begin{array}{l}\text { Ventral, dorsal and } \\
\text { lateral body plane }\end{array}$ & $4(0.3)$ & $9(0.8)$ & - & $11(0.9)$ & - & $1(0.1)$ & $25(2.1)$ & 17 \\
\hline Caudal region & $1(0.1)$ & $10(0.9)$ & - & $2(0.2)$ & - & $1(0.1)$ & $14(1.2)$ & 9.5 \\
\hline Head & - & $1(0.1)$ & - & - & - & - & $1(0.1)$ & 0.7 \\
\hline Pectoral fin & $1(0.1)$ & $4(0.3)$ & - & $1(0.1)$ & - & - & $6(0.5)$ & 4.1 \\
\hline Pelvic fin & - & $4(0.4)$ & - & - & - & - & $5(0.4)$ & 3.4 \\
\hline Snout & $1(0.1)$ & - & - & - & - & - & $1(0.1)$ & 0.7 \\
\hline Whole fish & $5(0.4)$ & $8(0.7)$ & - & $32(2.7)$ & - & - & $45(3.9)$ & 30.6 \\
\hline Eyes & - & 0 & - & $5(0.4)$ & - & - & $5(0.4)$ & 3.4 \\
\hline Mouth & - & 0 & - & $3(0.3)$ & - & - & $3(0.3)$ & 2 \\
\hline Total & $2.1 \%$ & $5 \%$ & $0.3 \%$ & $5.2 \%$ & $0.1 \%$ & $0.2 \%$ & $147(12.6)$ & - \\
\hline $\begin{array}{l}\text { \% Within } 12.6 \% \\
\text { infestation }\end{array}$ & 15.6 & 39.5 & 2 & 40.8 & 0.7 & 1.4 & - & 100 \\
\hline
\end{tabular}

Table 7. Percentage prevalence of Lernaea within fish species with respect to study periods.

\begin{tabular}{|c|c|c|c|c|c|}
\hline Study Period & Fish species & $\begin{array}{l}\text { Examined } \\
\text { samples }\end{array}$ & Infected samples & Prevalence \% & $\begin{array}{l}\text { Percentage } \\
\text { within } 12.6 \\
\text { prevalence }\end{array}$ \\
\hline \multicolumn{6}{|c|}{ Aug-Sep. } \\
\hline & Rahu, & 21 & 1 & $4.8 \%$ & \\
\hline & Grass carp & 15 & 2 & $13.3 \%$ & \\
\hline & Total & 36 & 3 & $8.3 \%$ & $2 \%$ \\
\hline \multicolumn{6}{|c|}{ Oct-Nov. } \\
\hline & Rahu & 40 & 2 & $5 \%$ & \\
\hline & Grass carp & 27 & 1 & $3.7 \%$ & \\
\hline & Mrigal carp & 5 & 0 & $0 \%$ & \\
\hline & Thella & 13 & 0 & $0 \%$ & \\
\hline & Silver & 5 & 0 & $0 \%$ & \\
\hline & Total & 90 & 3 & $3.3 \%$ & $2 \%$ \\
\hline \multicolumn{6}{|c|}{ Dec-Jan. } \\
\hline & Rahu & 262 & 21 & $8 \%$ & \\
\hline & Grass carp & 380 & 55 & $14.5 \%$ & \\
\hline & Mrigal carp & 32 & 3 & $9.4 \%$ & \\
\hline & Thella fish & 131 & 60 & $45.8 \%$ & \\
\hline & Silver carp & 1021 & 1 & $1 \%$ & \\
\hline & Tilapia & 105 & 0 & $0 \%$ & \\
\hline & Common carp & 26 & 2 & $7.7 \%$ & \\
\hline & Total & 1038 & 142 & $13.7 \%$ & $95.9 \%$ \\
\hline Overall & & 1164 & 147 & $12.6 \%$ & \\
\hline
\end{tabular}


According to Iqbal et al. (2012), 52.02\% to 57.80\% prevalence was calculated on the ventral side of fish and $23.12 \%$ to 27.13\% above the lateral line. However, in our study, it was calculated as $0.6 \%$ and $2.1 \%$ in ventral body plane and ventral, dorsal and lateral body planes.

Our study showed the highest prevalence occurred from December to January. Besides, Iqbal et al. (2001b), Iqbal et al. (2012), and Tasawar et al. (1999) detected the highest incidence of the parasite till late winter (December to April) where the water temperature remained in the range of $13-23{ }^{\circ} \mathrm{C}$ and low parasite incidence during the summer. Ullah et al. (2018) reported heavy infestation during summer and low during winter. The impact of water temperature variations on the Lernaea outbreaks has also been reported by Dalu et al. (2012) and Idris and Amba (2011). Therefore, the seasonal variations in the parasite prevalence in fish species is yet an open question, and a lot more research is required to establish it. Alam et al. (2012) proposed that monthly variations could be elucidated by fish feeding, water depth, temperature, and other physicochemical parameters. We also found that the Lernaea infestation reaches at peak during the cold rainy season, as also reported by Fryer (1982), Mbahinzireki (1984), M'balaka (2018), and Kabata (1985).

Previously, Berry Junior et al. (1991), Raissy et al. (2013), and Stavrescu-Bedivan et al. (2014) observed that increased water temperature could influence the intensity of $L$. cyprinacea. The optimum water temperature for its development is above $20^{\circ} \mathrm{C}$, and at a higher temperature, it can increase growth and shorten generation time (Piasecki and Avenant-Oldewage, 2008). Therefore, the $25{ }^{\circ} \mathrm{C}$ temperature reported in this study is ideal for parasite propagation, while $13{ }^{\circ} \mathrm{C}$ was recorded for survival in winter. The life cycle is temperature-dependent, whereas the prevalence and intensity decrease with decreasing temperature in winter (Mancini et al., 2006; Mancini et al., 2008). Similarly, Abbas et al. (2014), reported an increase in the parasite prevalence increasing with the rise in water temperature in the summer season. The life cycle of most species of Lernaea is completed in 100 days at $14{ }^{\circ} \mathrm{C}$ and 21 days at $28^{\circ} \mathrm{C}$, but the optimum water temperature falls between $23-30{ }^{\circ} \mathrm{C}$. Fryer (1982) reported that Lernaea in Japan lasted for approximately four weeks at $27{ }^{\circ} \mathrm{C}$ and for five weeks at $22^{\circ} \mathrm{C}$ but could prevail fora longer time during the winter season as they can thrive for five to six months. Hossain et al. (2018) observed intense infestation (72\%) of Lernaea during January -March, with the lowest (8\%) during April - June. In contrast, we observed the highest prevalence (13.6\%) recorded during December -January and the lowest (3.3\%) during August -September.

Some researchers like Abbas et al. (2014) and Moghadam et al. (2009) presented that small-sized fishes have shown higher parasitic infection rates. Still, others believed the infection rate increases with increasing fish body weight and length. Mirzaei (2015) cited that anchor worms readily infected the small fish. This study showed that the prevalence of Lernaea was more significant in younger fishes but decreased with the increase of body weight. However, in our case, the parasitic prevalence increased in fish weighing higher than 2001-4000 g, and these findings are in accordance with Tasawar et al.
(2009) and Wagner et al. (2002). These results are also in line with Fryer (1982) and M'balaka (2018), who reported that small-sized (fingerling) Balitora meridionalis (Kottelat, 1988) was less vulnerable to L. cyprinacea than large-sized fishes of the same species.

Similarly, Fryer (1982) reported that chances of smallsized fish like Haplochromis spp. which rarely exceed $150 \mathrm{~mm}$, were very slim compared to tilapias, whose size may reach up to $350 \mathrm{~mm}$ in length. Potentially, the larger body size offers more surface area for the parasitic invasion. In Pakistan, Kanwal et al. (2012) reported that higher-weight fishes mostly got infested than the lowerweight fish samples. Tasawar et al. (2009) specified that different weight groups with varying prevalence rates could be due to differences in fish scales orientation. Innal and Avenant-Oldewage (2012) determined a problematic correlation between the fish growth rate and infestation intensity of lernaeid parasites.

According to Innal et al. (2017), both biotic and abiotic and seasonal factors include water quality, fish feeding, size, fish reproductive biology, parasite attachment preferences, and host-parasite coevolution are involved in the incidence of lernaeid parasites. Climatic factors and environmental conditions play a considerable role in the prevalence of Lernaeid ectoparasites at different locations (Ahmed et al., 2001; Buchmann and Lindenstrom, 2002) along with the stocking density (Bashak et al., 2021). Factors like ecological and climatic conditions show a significant role in Lernaeid ectoparasite incidence in various regions and localities (Ahmed et al., 2001; Ali et al., 2014; Buchmann and Lindenstrom, 2002). Infection rate and intensity also differed between various fish species, and this phenomenon may be linked to varying fish biology (Iqbal et al., 2012).

\section{Conclusion}

We investigated the prevalence lernaeid parasites in public and private fish farms where Indian major carps and Chinese carps are mainly cultured. During our study, we identified 12 lernaeid species in the seven most popular cultivated fish species. The outcomes provided useful insights into the lernaeid infestation and prevalence as well as potential treatment options used by the fish farmers to control to breakout. A combination of lime and $\mathrm{KMnO}_{4}$ appeared to be the most effective treatment option used by the farmers. As the diversity and prevalence of Lernaea species are increasing in Pakistan's freshwater fish species, the Lernaea infestations vary with respect to farm location, body organs and water temperatures. Therefore, the Lernaea species identification by molecular techniques could help to control this issue in future. Furthermore, this study provides useful insights into the most prevalent types of anchor worms in edible fish species in the Pakistan aquaculture industry. Since this study provides practical details on how to identify the potential parasites in fish and the most vulnerable parts of the fish body, this study offers a suitable option for the future researchers to follow. Furthermore, these findings can be applied at the local to regional scales. 


\section{Acknowledgements}

We wish to thank all fish farmers for their cooperation to provide data and specimens for this research trial. We also wish to thank Syed Ghulam Mohayud Din Hashmi, Lecturer, Geographic Information System (GIS) Laboratory, Department of Wildlife and Ecology, University of Veterinary and Animal Sciences, Lahore, Pattoki, Ravi Campus, Punjab, Pakistan for help in construction of map of study area.

\section{References}

ABBAS, F., ASHRAF, M. and REHMAN, M.H., 2014. Lernaea susceptibility, infestation and its treatment in indigenous major and exotic Chinese carps under polyculture system. Pakistan Journal of Zoology, vol. 46, no. 5, pp. 1215-1222.

ABBAS, S., IQBAL, A., ANJUM, K.M., SHERZADA, S., ATIQUE, U., KHAN, M.K.A., AKMAL, M., RAHMAN, A., ASIF, A.R., AHMAD, S., MALIK, A., KHAN, S.A., AHMAD, S., INAYAT, M., 2023. Body composition, growth performance and enzyme activities of Labeo rohita fed different commercial fish feeds. Brazilian Journal of Biology, vol. 83, pp. 250402. https://doi.org/10.1590/1519-6984.250402.

AHMED, M.S., KAUSAR, M. and KHAN, W.A., 2001. Prevalence of Lernaea cyprinacea (Crustacean: Copepoda) in Indian major carps. Science International, vol. 13, no. 1, pp. 83-85.

ALAM, M.M., KHAN, M.A., HUSSAIN, M.A., MOUMITA, D., MAZLAN, A.G. and SIMON, K.D., 2012. Intensity of parasitic infestation in silver carp, H. molitrix. Journal of Zhejiang University. Science B., vol. 13, no. 12, pp. 1024-1028. http://dx.doi.org/10.1631/jzus. B1200121. PMid:23225858.

ALI, A., HAYAT, S., AHMED, M.S., ELAHI, N., SAGHIR, A., ALI, H. and KHAN, W.A., 2014. Prevalence of Lernaeid Ectoparasites in some Culturable Fish species from different Nurseries of Punjab. Biologia, no. 601, pp. 123-127.

ATIQUE, U., IQBAL, S., KHAN, N., QAZI, B., JAVEED, A., ANJUM, K.M., HAIDER, M.S., KHAN, T.A., MAHMOOD, S. and SHERZADA, S., 2020. Multivariate Assessment of water chemistry and metals in a river impacted by tanning industry. Fresenius Environmental Bulletin, vol. 29, pp. 3013-3025.

BASHAK, S.K., PAUL, A.K., HOSSAIN, M.A., ATIQUE, U., IQBAL, S., UDDIN, M.N., FARHADUZZAMAN, A.M., RAHMAN, M.M., ISLAM, M.S., 2021. Growth Performance and Culture Economics of Mud Eel Semi-Intensively Cultured Under Varying Stocking Densities in Rain-fed Earthen Ponds. Punjab University Journal of Zoolofy, vol.36, pp. 101-110. https://doi.org/10.17582/JOURNAL. PUJZ/2021.36.1.101.110.

BATOOL, S.S., KHAN, N., ATIQUE, U., AZMAT, H., IQBAL, K.J., MUGHAL, D.H., AHMAD, M.S., BATOOL, S., MUNAWAR, S., DOGAR, S., NAWAZ, M. and AMJAD, S., 2018. Impact of azomite supplemented diets on the growth and body composition of catfish (Pangasius hypophthalmus). Pakistan Journal of Zoology, vol. Suppl. Ser, pp. 8-12.

BERRY JUNIOR, C.R., BABEY, G.J. and SHRADER, T., 1991. Effect of Lernaea cyprinacea (Crustacea: Copepoda) on stocked rainbow trout (Oncorhynchus mykiss). Journal of Wildlife Diseases, vol. 27, no. 2, pp. 206-213. http://dx.doi.org/10.7589/0090-355827.2.206. PMid:2067042.

BUCHMANN, K. and LINDENSTRØM, T., 2002. Interactions between monogenean parasites and their fish hosts. International Journal for Parasitology, vol. 32, no. 3, pp. 309-319. http:// dx.doi.org/10.1016/S0020-7519(01)00332-0. PMid:11835971.

DALU, T., NHIWATIWA, T. and CLEGG, B., 2012. Impact of Lernaea cyprinacea Linnaeus 1758 (Crustacea: Copepoda) almost a decade after an initial parasitic outbreak in fish of Malilangwe
Reservoir, Zimbabwe. Knowledge and Management of Aquatic Ecosystems, vol. 406, no. 3, pp. 1-9. http://dx.doi.org/10.1051/ kmae/2012020.

FRYER, G., 1982. The parasitic Copepoda and Branchiura of British freshwater fishes: a handbook and key. United Kingdom: Freshwater Biology Association.

HAIDER, M.S., JAVID, A., AZMAT, H., ABBAS, S., ASHRAF, S., ALTAF, M., ATIQUE, U., IQBAL, S., IQBAL, K.J. and BAOOL, M., 2018. Effect of processed fish waste on growth rate and digestive enzymes activities in Cyprinus carpio. Pakistan Journal of Zoology, vol. Suppl. Ser, pp. 191-198.

HEMAPRASANTH, K.P., RAGHAVENDRA, A., SINGH, R., SRIDHAR, N. and RAGHUNATH, M.R., 2008. Efficacy of doramectin against natural and experimental infections of Lernaea cyprinacea in carps. Veterinary Parasitology, vol. 156, no. 3-4, pp. 261-269. http://dx.doi.org/10.1016/j.vetpar.2008.06.005. PMid:18650018.

HEMAPRASANTH., SINGH, R., RAGHAVENDRA, A., SRIDHAR, N., RAGHUNATH, M.R. and EKNATH, A.E., 2011. Comparative susceptibility of carp fingerlings to Lernaea cyprinacea infection. Veterinary Parasitology, vol. 178, no. 1-2, pp. 156-162. http:// dx.doi.org/10.1016/j.vetpar.2010.12.029. PMid:21255932.

HOFFMAN, G.L., 2019. Parasites of North American freshwater fishes. Ithaca: Cornell University Press.

HOSSAIN, M.M.M., FERDOUSHI, J. and RUPOM, A.H., 2018. Biology of anchor worms (Lernaea cyprinacea). Journal of Entomology and Zoology Studies, vol. 6, no. 1, pp. 910-917. http://dx.doi. org/10.22271/j.ento.2018.v6.i1m.3047.

HUA, C.J., ZHANG, D., ZOU, H., LI, M., JAKOVLIĆ, I., WU, S.G., WANG, G.T. and LI, W.X., 2019. Morphology is not a reliable taxonomic tool for the genus Lernaea: molecular data and experimental infection reveal that $L$. cyprinacea and $L$. cruciata are conspecific. Parasites E Vectors, vol. 12, no. 1, pp. 579. http://dx.doi. org/10.1186/s13071-019-3831-y. PMid:31829242.

IDRIS, H.B. and AMBA, M.A., 2011. A note on Lernaea cyprinacea parasitizing the cultured marble goby Oxyeleotris marmorata and their control with salinity modification. Advances in Environmental Biology, vol. 5, no. 5, pp. 817-820.

INNAL, D. and AVENANT-OLDEWAGE, A., 2012. Occurrence of Lernaea cyprinacea on mosquito fish (Gambusia affinis) from Kundu Estuary (Antalya-Turkey). Bulletin of the European Association of Fish Pathologists, vol. 32, no. 4, pp. 140-147.

INNAL, D., AVENANT-OLDEWAGE, A. and DOGANGIL, B., 2017. Susceptibility of endemic and non-indigenous fish to Lernaea cyprinacea (Copepoda: Lernaeidae): a case study from Düger Spring Creek (Burdur-Turkey). Bulletin of the European Association of Fish Pathologists, vol. 37, no. 3, pp. 100-109.

IQBAL, K.J., JAVID, A., KHAN, N., BABOO, I., ALI, A., MOHSIN, K., ANWER, A., ATIQUE, U., ALTAF, M., HUSSAIN, D. and CHAUDHRY, A., 2020a. Consumer attitude towards wild-caught and farmraised fish in Bahawalpur. Biologia, vol. 66, pp. 11-17.

IQBAL, S., ATIQUE, U., MAHBOOB, S., HAIDER, M.S., IQBAL, H.S., ALGHANIM, K.A., AL-MISNED, F., AHMED, Z. and MUGHAL, M.S., 2020b. Effect of supplemental selenium in fish feed boosts growth and gut enzyme activity in juvenile tilapia (Oreochromis niloticus). Journal of King Saud University Science., vol. 32, no. 5, pp. 2610-2616. http://dx.doi.org/10.1016/j.jksus.2020.05.001.

IQBAL, S., ATIQUE, U., MUGHAL, M.S., YOUNUS, M., RAFIQUE, M.K., HAIDER, M.S., IQBAL, H.S., SHERZADA, S. and KHAN, T.A., 2020c. Selenium-supplemented diet influences histological features of liver and kidney in Tilapia (Oreochromis niloticus). Jordan Journal of Biological Sciences, vol. 13, pp. 453-461.

IQBAL, Z., MINHAS, I.K. and KHAN, M.N., 2001a. Aquaculture development in Punjab, Pakistan: a case study. Science International, vol. 13, pp. 283-288. 
IQBAL, Z., MINHAS, I.K. and KHAN, M.N., 2001b. Seasonal occurrence of lernaeasis in pond aquaculture in Punjab. Proceedings of Pakistan Congress of Zoology, vol. 21, pp. 159-168.

IQBAL, Z., SHAFQAT, A. and HAROON, F., 2012. Lernaea diversity and infection in Indian and Chinese carps under semi-intensive culture conditions in Lahore. Punjab Journal of Animal and Plant Sciences, vol. 22, pp. 923-926.

JEWEL, M.A.S., ALI, S.M.W., HAQUE, M.A., AHMED, M.G.U., IQBAL, S., ATIQUE, U., PERVIN, M.E. and PAUL, A.K., 2020. Growth and economics of silver barb (Barbonymus gonionotus) in ricefish-vegetable integrated culture system at different stocking densities in a rainfed arid zone. Egyptian Journal of Aquatic Biology and Fisheries, vol. 24, no. 6, pp. 459-476. http://dx.doi. org/10.21608/ejabf.2020.117948.

KABATA, Z., 1985. Parasites and diseases of fish cultured in the tropics. London: Taylor \& Francis.

KANWAL, N., SIRAJ, Z. and TASAWAR, Z., 2012. The Lernaeid parasites of Catlacatla. Acta ParasitologicaGlobalis, vol. 3, no. 2, pp. 16-19.

KHALIFA, K.A. and POST, G., 1976. Histopathological effect of Lernaea cyprinacea (a copepod parasite) on fish. Progressive Fish-Culturist, vol. 38, no. 2, pp. 110-113. http://dx.doi.org/10.1577/15488659(1976)38[110:HEOLCA]2.0.CO;2

LESTER, R.G. and HAYWARD, C.J., 2006. Phylum arthropoda. In: P.T.K. WOO, ed. Fish diseases and disorders: protozoan and metazoan infections. Wallingford: CAB International, vol. 1, pp. 466-565. http://dx.doi.org/10.1079/9780851990156.0466.

M'BALAKA, M.S., 2018. Incidence of Lernaea cyprinacea on Lake Malawi Kampango (Bagrusmeridionalis). International Journal of Fisheries and Aquatic Studies, vol. 6, no. 3, pp. 25-30.

MANCINI, M., RODRIGUEZ, C. and ORTIZ, M., 2008. Lerneosisenpecessilvestres y cultivados del centro de Argentina. Biologia Acuatica, vol. 24, pp. 33-41.

MANCINI, M., RODRIGUEZ, C., PROSPERI, C., SALINAS, V. and BUCCO, C., 2006. Main diseases of pejerrey (Odontesthesbonariensis) in central Argentina. Pesquisa Veterinária Brasileira, vol. 26, no. 4, pp. 205-210. http://dx.doi.org/10.1590/S0100736X2006000400004.

MARGOLIS, L. and KABATA, Z., 1988. Guide to the parasites of fishes of Canada: Part II: Crustacea. Ottawa: Department of Fisheries and Oceans.

MBAHINZIREKI, G.B.A., 1984. Parasite fauna of haplochromis species (pisces: cichilidae) from Mwanza gulf of Lake Victoria. Dar es Salaam: University of Dar es Salaam, 155 p. Doctoral Dissertation in Science.

MEHBOOB, A., KHAN, N., ATIQ U., IQBAL, K.J., TAYYAB, R., BATOOL, S.S., BATOOL, H.S., AMJAD, S. and TANVEER, M., 2017. Effect of Fenugreek as a Feed Additive on the Growth, Body Composition and Apparent Nutrients Digestibility of Striped Catfish Pangasius hypophthalmus Fry. Pakistan Journal of Zoology, vol. 49, no. 6, pp. 2037-2042. http://dx.doi.org/10.17582/journal. pjz/2017.49.6.2037.2042.

MIRZAEI, M., 2015. Prevalence and histopathologic study of Lernaea cyprinacea in two species of ornamental fish (Poecilialatipinna and Xiphophorushelleri) in Kerman, South-East Iran. Turkiye Parazitoloji Dergisi, vol. 39, no. 3, pp. 222-226. http://dx.doi. org/10.5152/tpd.2015.3960. PMid:26470930.

MOGHADAM, S.B., MOKHAYER, B. and MASOULEH, A.S., 2009. Parasite infection among larvae and fingerling of the Persian sturgeon (Acipenser persicus) in Vitro tank and earthen ponds. Iranian Journal of Fisheries Science, vol. 9, pp. 342-351.

MONOD, T., 1932. Contribution à l'étude de quelquescopépodes parasites de poissons. Annales de Parasitologie Humaine et Comparee, vol. 10, no. 4, pp. 345-380. http://dx.doi.org/10.1051/ parasite/1932104345.
NANDEESHA, M.C., DEVARAJ, K.V. and MURTHY, C.K., 1984. Incidence of crustacean parasite Lernaea bhadraensis on fingerlings of Labeo fimbriatus (Bloch). Current Research, vol. 13, pp. 80-82.

NANDEESHA, M.C., SEENAPPA, D. and DEVARAJ, K.V., 1985. Incidence of anchor worm Lernaea on new hosts of fishes. Environment and Ecology, vol. 3, pp. 293-295.

PIASECKI, W. and AVENANT-OLDEWAGE, A., 2008. Diseases caused by Crustacea. Fish Diseases, vol. 2, pp. 1115-1200.

PIASECKI, W., GOODWIN, A.E. and EIRAS, J.C., 2004. Importance of Copepoda in freshwater aquaculture. Zoological Studies, vol. 43, no. 2, pp. 193-205.

RAHNAMA, M., KHEDRI, J. and MOKHTARI, M.S., 2016. Prevalence and histopathologic study of Lernaea spp. (Maxillopoda: Lernaeidae) in Cyprinus carpio fish in Sistan and Baluchestan, Southeast Iran. Revista Scientia Parasitologica, vol. 17, no. 1-2, pp. 43-48.

RAISSY, M., SOHRABI, H.R. and RASHEDI, M., 2013. Investigation of a parasitic outbreak of Lernaea cyprinacea Linnaeus (Crustacea: Copepoda) in Cyprinid fish from Choghakhor lagoon. Iranian Journal of Fisheries Science, no. 12, pp. 680-688.

RAY, S., MONDAL, P., PAUL, A.K., IQBAL, S., ATIQUE, U., ISLAM, M.S., MAHBOOB, S., AL-GHANIM, K.A., AL-MISNED, F., BEGUM, S., 2021. Role of shrimp farming in socio-economic elevation and professional satisfaction in coastal communities. Aquaculture Reports, vol. 20, pp. 100708. https://doi.org/10.1016/j. aqrep.2021.100708

SAYYADZADEH, G., ESMAEILI, H.R. and GHASEMIAN, S., 2016. Co-invasion of anchor worms Lernaea cyprinacea (Copepoda: Lernaeidae) in some freshwater fishes of the Kor River Basin, Southwest of Iran with some remarks on the ecological aspects of lernaeosis in the country. Iranian Journal of Fisheries Science, vol. 15, no. 1, pp. 369-389.

STAVRESCU-BEDIVAN, M.M., POPA, O.P. and POPA, L.O., 2014. Infestation of Lernaea cyprinacea (Copepoda: Lernaeidae) in two invasive fish species in Romania, Lepomis gibbosus and Pseudorasbora parva. Knowledge and Management of Aquatic Ecosystems, no. 414, pp. 12. http://dx.doi.org/10.1051/ kmae/2014024.

TAMULI, K.K. and SHANBHOGUE, S.L., 1996. Incidence and intensity of anchor worm Lernaea bhadraensis infection on cultivated carps. Environment and Ecology, vol. 14, no. 2, pp. 282-288.

TASAWAR, Z., HANIF, M. and LASHARI, M.H., 2007. The prevalence of lernaeid ectoparasites in Mori (Cirrhinusmrigala) fish. Pakistan Veterinary Journal, vol. 27, no. 4, pp. 176.

TASAWAR, Z., NASEEM, R. and AKHTAR, M., 1999. Prevalence of copepod ectoparasites of grass carp Ctenopharyngodon idella. Pakistan Journal of Biological Sciences, vol. 2, no. 3, pp. 10531054. http://dx.doi.org/10.3923/pjbs.1999.1053.1054.

TASAWAR, Z., NAZ, F. and LASHARI, M., 2009. Incidence of lernaeid parasite in Catlacatla on a fish farm. Sarhad Journal of Agriculture, vol. 25, no. 2, pp. 285-289.

TAVARES-DIAS, M. and MARTINS, M.L., 2017. An overall estimation of losses caused by diseases in the Brazilian Fish farms. Journal of Parasitic Diseases, vol. 41, no. 4, pp. 913-918. http://dx.doi. org/10.1007/s12639-017-0938-y.

ULLAH, I., KHAN, M.F., KHAN, M.S., KHAN, S.U., HUSSAIN, S., JAVID, M., 2018. Copepod ecto-parasites of Labeo rohita from Dera Ismail Khan, Khyber Pakhtunkhwa Pakistan. Journal of Entomology and Zoology Studies, vol. 6, no. 5, pp. 1077-1076.

WAGNER, E., ARNDT, R., BROUGH, M. and ROBERTS, D.W., 2002. Comparison of susceptibility of five cutthroat trout strains to Myxoboluscerebralis infection. Journal of Aquatic Animal Health, vol. 14, no. 1, pp. 84-91. http://dx.doi.org/10.1577/15488667(2002)014<0084:COSOFC >2.0.CO;2. 